\title{
Field experimental design for pesticide leaching - a modified large-scale lysimeter
}

\author{
Bertel Nilsson, Jens Aamand, Ole Stig Jacobsen and René K. Juhler
}

Recent research on Danish groundwater has focused on clarifying the fate and transport of pesticides that leach through clayey till aquitards with low matrix permeability. Previously, these aquitards were considered as protective layers against contamination of underlying groundwater aquifers due to their low permeability characteristics. However, geological heterogeneities such as fractures and macropores have been recognised as preferential flow paths within low permeable clayey till (e.g. Beven \& Germann 1982). The flow velocities within these preferential flow paths can be orders of magnitude higher than in the surrounding clay matrix and pose a major risk of transport of contaminants to the underlying aquifers (e.g. Nilsson et al. 2001).

Previous studies of transport in fractured clayey till have focused on fully saturated conditions (e.g. Sidle et al. 1998; McKay et al. 1999). However, seasonal fluctuations of the groundwater table typically result in unsaturated conditions in the upper few metres of the clay deposits, resulting in different flow and transport conditions. Only a few experiments have examined the influence of unsaturated conditions on flow and solute (the dissolved inorganic and organic constituents) transport in fractured clayey till. These include smallscale laboratory column experiments on undisturbed soil monoliths (e.g. Jacobsen et al. 1997; Jørgensen et al. 1998), intermediate scale lysimeters (e.g. Fomsgaard et al. 2003) and field-scale tile drain experiments (e.g. Kjær et al. 2005). The different approaches each have limitations in terms of characterising flow and transport in fractured media. Laboratory studies of solute transport in soils (intact soil columns) are not exactly representative of field conditions due to variations in spatial variability and soil structure. In contrast, field studies hardly allow quantification of fluxes and mechanisms of transport. Column and lysimeter experiments are often limited in size, and tile-drain experiments on field scale do not provide spatial resolution and often have large uncertainties in mass balance calculations. Thus, in order to represent the overall natural fracture network systems on a field scale with respect to acquiring insights into flow and transport processes, the lysimeter needs to be larger than normal lysimeter size $\left(<1 \mathrm{~m}^{3}\right)$. A modified large-scale lysimeter was therefore constructed by the Geological Survey of Denmark and Greenland (GEUS) at the Avedøre experimental field site 15 $\mathrm{km}$ south of Copenhagen (Fig. 1). This lysimeter consisted of an isolated block $(3.5 \times 3.5 \times 3.3 \mathrm{~m})$ of unsaturated fractured clayey till with a volume sufficient to represent the overall preferential flow paths (natural fracture network) within lowpermeable clayey till at a field scale.
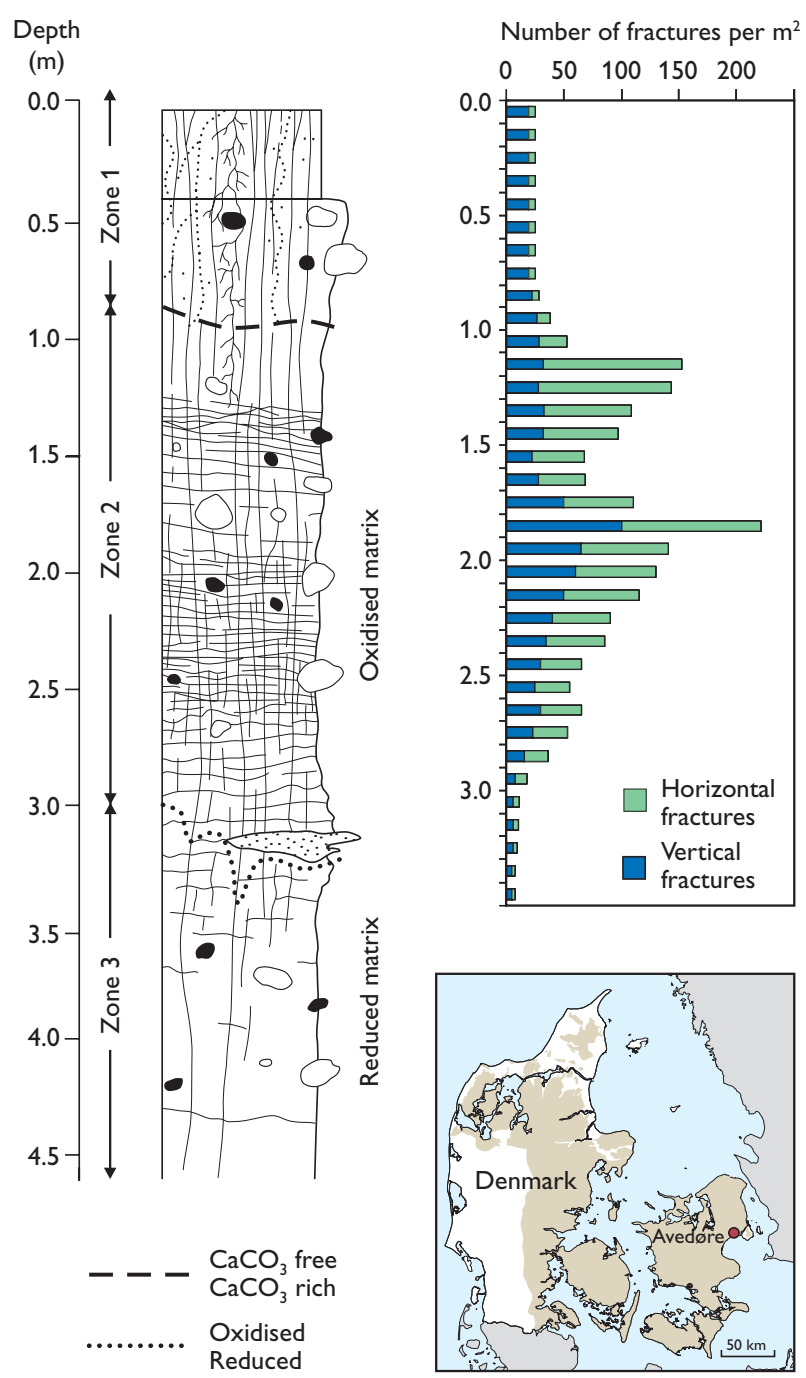

Fig. 1. Lithology and fracture frequency of the clayey till found at the Avedøre field site where a large-scale lysimeter experiment was carried out. Inset map: Location of the field site. The brown colour indicates the distribution of the clayey till plain in Denmark that was previously considered to be a protective layer against contamination of underlying aquifers from surface applications of pesticides. Modified from Mortensen et al. (2004), 


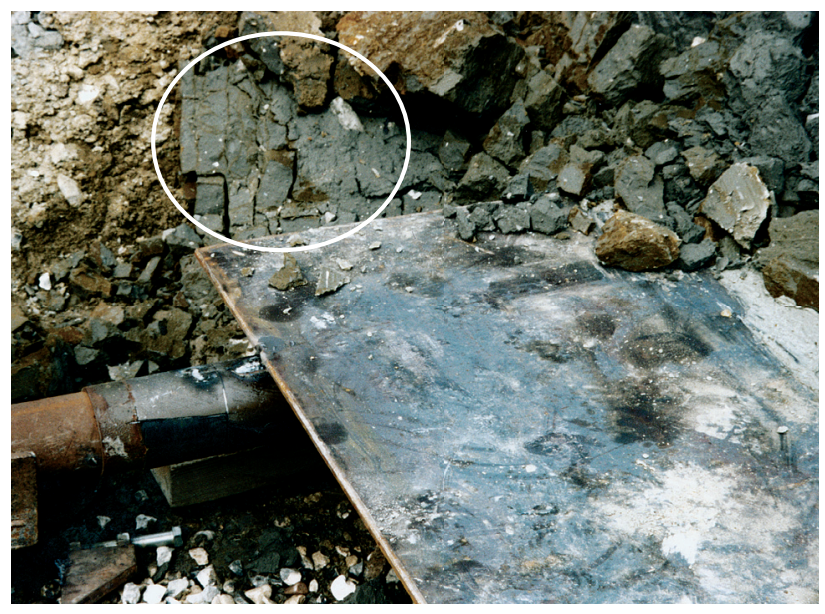

Fig. 2. Clayey till as seen at $3.3 \mathrm{~m}$ depth at the Avedøre field site. Two vertical and one horizontal fracture systems give the till a brick-like appearance. The steel plate forms the bottom of the lysimeter.

\section{Field site description}

The till plain at the Avedøre field site is characterised by a 7 $\mathrm{m}$ thick, highly fractured clayey till aquitard covering a regional limestone aquifer. Lithology, fracture systems and macropores have been measured at the study site (Fig. 1) in order to describe the depositional environment (McKay et al. 1999). The fracture characterisation indicates that five distinct fracture systems are present in the till aquitard at the field site. Two vertical fracture systems and one horizontal give the till a brick-like appearance between about 1.25 to 3.3 $\mathrm{m}$ depth (Fig. 2). The till consists of massive and very stiff clayey material that has always caused problems to well borers and contractors in the Copenhagen area due to the material hardness. It was therefore no surprise that difficulties

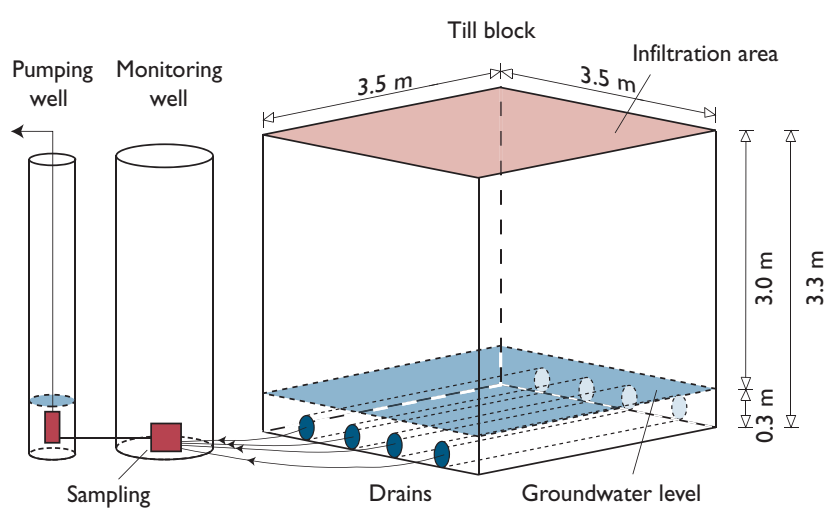

Fig. 3. Experimental set-up showing the large-scale lysimeter that consists of an isolated till block, and the adjacent monitoring and pumping wells. Modified from Mortensen et al. (2004).

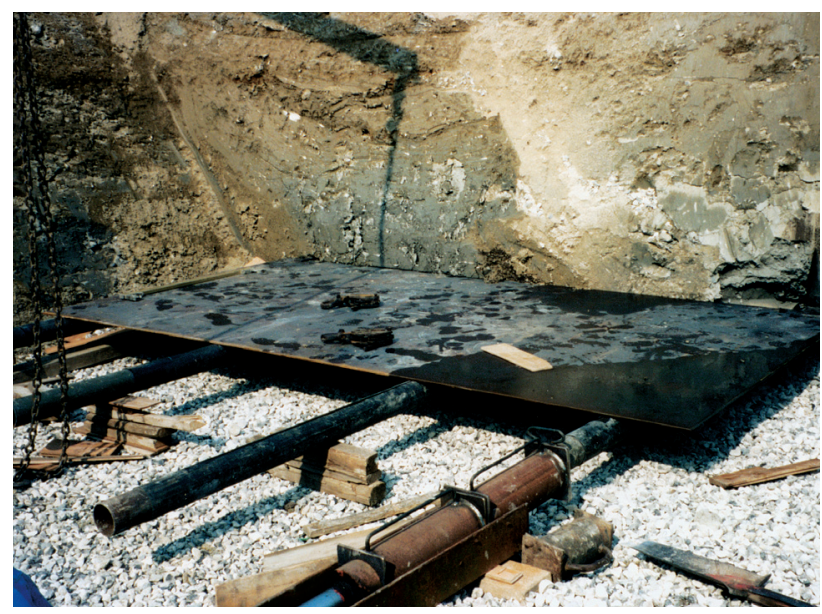

Fig. 4. Installation of the steel plate forming the base of the large-scale lysimeter. The steel plate was inserted by four hydraulic piston rods into the wall of the excavation at $3.3 \mathrm{~m}$ depth.

were encountered during construction of tunnels below central parts of the city of Copenhagen for the recently completed metro train system.

\section{Modified large-scale lysimeter}

The lysimeter consists of an isolated till block (Fig. 3), where the lower boundary is a steel plate (Fig. 4), and the vertical walls around the block have been isolated with prefabricated bentonite plates to avoid water invasion from the surrounding environment. For monitoring and controlling transport through the block, four horizontal drainpipes were installed above the steel plate. The design of the modified lysimeter is described in detail in Mortensen et al. (2004).

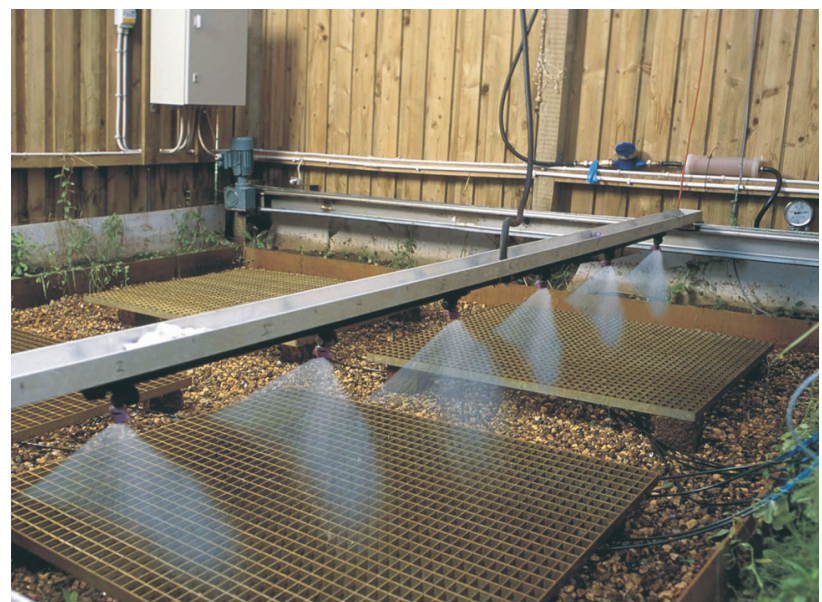

Fig. 5. Computer-controlled spraying system providing controlled amounts of water to the till block to facilitate pesticide leaching. The pesticides and tracer compounds were added directly to the surface of the till block. 
The exposed upper surface of the block (infiltration area) is covered by a shelter to protect it from unmeasured contributions of rainfall. Controlled artificial precipitation can be generated over the infiltration basin (Fig. 5) using a computer-controlled spray system. The nozzles on the spray system are identical with nozzles traditionally used for agricultural pesticide spraying.

\section{Pesticide leaching through an isolated block of clayey till}

A multiple tracer experiment and two different pesticideleaching experiments were carried out using the lysimeter, with precise control of the rain distribution and percolation through the lysimeter. The diffusive exchange of pesticides and multiple tracers between fractures and the matrix was examined in the lysimeter whereas specific sorption and degradation rates were determined in the laboratory. Cored samples were collected in a $3.5 \mathrm{~m}$ deep excavation adjacent to the lysimeter for the laboratory work (Fig. 6).
Results of the multiple tracer experiment are reported by Mortensen et al. (2004). Tracers during steady-state flow were transported quickly through the $3.3 \mathrm{~m}$ unsaturated clayey till block, with the first tracer being detected after about 25 minutes. Multiple tracing techniques were applied to evaluate the importance of diffusive exchange on the overall transport processes. The main finding of the multiple tracer study was that there were large differences for the three different water fluxes used. The results of the pesticide leaching experiments provided some insights into the transport mechanisms in fractured clay, and verified a need for further work on leaching experiments in large-scale lysimeters. It is essential that transport mechanisms are addressed by the experimental conditions provided by lysimeters such as that described here. Only through such experiments can plausible quantifications of mass fluxes be obtained. Results of these studies have been reported in detail by Aamand \& Jacobsen (2001), Juhler \& Mortensen (2002), Nilsson et al. (2002), Mortensen et al. (2004) and Aamand et al. (in press).
Fig. 6. Large excavation close to the lysimeter at the Avedøre field site. The pit was excavated in steps with vertical and horizontal faces. Profiles were orientated in two directions, perpendicular to one another, so that the fracture characterisation could be expressed in three dimensions. Cored samples from matrix and fracture dominated parts were collected for degradation, sorption and pesticide diffusion studies in the laboratory.

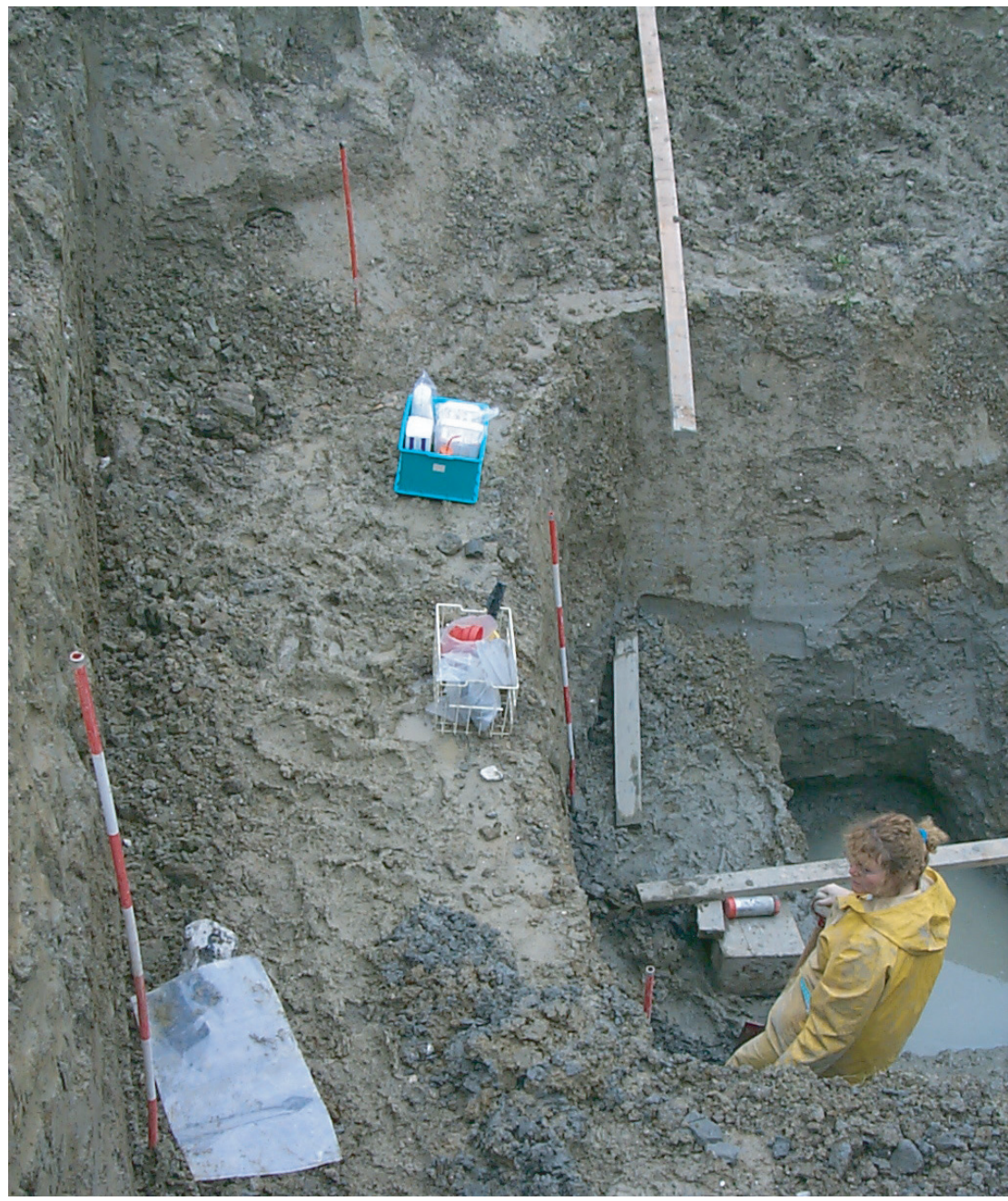




\section{Acknowledgement}

This paper is an outcome of various combined laboratory and field studies (together named the Avedøre Project) initially carried out during 2000-2001 by the Geological Survey of Denmark and Greenland (GEUS) in collaboration with the Technical University of Denmark and Københavns Energi. A follow-up experiment was carried out during 2003-2004 by GEUS in collaboration with the Geological Institute, University of Copenhagen.

\section{References}

Aamand, J. \& Jacobsen, O.S. 2001: Sorption and degradation of glyphosate and dichlobenil in fractured clay. In: Walker, A. (ed.): Pesticide behaviour in soils and water. BCPC Symposium Proceedings 78, 205-210.

Aamand, J., Jacobsen, O.J. \& Nilsson, B. in press: Glyphosats transport og omsætning i sprækket moræneler. Danmarks og Grønlands Geologiske Undersøgelse Rapport.

Beven, K. \& Germann, M. 1982: Macropores and water flow in soils. Water Resources Research 18, 1311-1325.

Fomsgaard, I.S., Spliid, N.H. \& Felding, G. 2003: Leaching of pesticides through normal-tillage and low-tillage soil - a lysimeter study. I. Isoproturon. Journal of Environmental Science and Health B38, 1-18.

Jacobsen, O.H., Moldrup, P., Larsen, C., Konnerup, L. \& Petersen, L.W. 1997: Particle transport in macropores of undisturbed soil columns. Journal of Hydrology 196, 185-203.
Jørgensen, P.R., McKay, L.D. \& Spliid, N.H. 1998: Evaluation of chloride and pesticide transport in a fractured clayey till using large undisturbed columns and numerical analysis. Water Resources Research 34, 539-553.

Juhler, R.K. \& Mortensen, A.P. 2002: Analysing fluorobenzoate tracers in groundwater samples using liquid chromatography - tandem mass spectrometry - a tool for leaching studies and hydrology. Journal of Chromatography A957, 11-16.

Kjær, J., Olsen, P., Ullum, M. \& Grant, R. 2005: Leaching of glyphosate and amino-methylphosphonic acid from Danish agricultural field sites. Journal of Environmental Quality 34, 608-621.

McKay, L., Fredericia, J., Lenczewski, M., Morthorst, J. \& Klint, K.E.S. 1999: Spatial variability of contaminant transport in a fractured till, Avedøre, Denmark. Nordic Hydrology 30, 333-360.

Mortensen, A.P., Jensen, K.H., Nilsson, B. \& Juhler, R.K. 2004: Multiple tracing experiments in unsaturated fractured clayey till. Vadose Zone Journal 3, 633-644.

Nilsson, B., Sidle, R.C., Klint, K.E., Bøggild, C.E. \& Broholm, K. 2001: Mass transport and scale-dependent hydraulic tests in a heterogeneous glacial till-sandy aquifer system. Journal of Hydrology $\mathbf{2 4 3}$, 162-179.

Nilsson, B., Aamand, J., Jacobsen, O.S., Juhler, R.K., Mortensen, A.P. \& Broholm, M. 2002: Udvalgte pesticiders transportveje og omsætning i sprækket moræeneler i Københavnsområdet. Danmarks og Grønlands Geologiske Undersøgelse Rapport 2002/34, 62 pp.

Sidle, R.C., Nilsson, B., Hansen, M. \& Fredericia, J. 1998: Spatially varying hydraulic and solute transport characteristics of a fractured till determined by field tests, Funen, Denmark. Water Resources Research 34, 2515-2517.

\section{Authors' address}

Geological Survey of Denmark and Greenland, Øster Voldgade 10, DK-1350 Copenhagen K, Denmark. E-mail: bn@geus.dk 